\section{The Effect of Olive Tree Stock Plant Nutritional Status on Propagation Rates}

Arnon Dag', Ran Erel, Alon Ben-Gal, Isaac Zipori, and Uri Yermiyahu Gilat Research Center, Agricultural Research Organization, M.P. Negev, 85280, Israel

Additional index words. Olea europaea, nitrogen, phosphorous, potassium, rooting, fertilization

Abstract. The global production of olives (Olea europaea L.) has increased rapidly over the last decade as a result of the expansion of orchards with high tree densities. Most olives are propagated from rooted cuttings. The present study evaluated the propagation rate of rooted cuttings as a function of the nutritional status of the stock trees. Rooting ability was evaluated for cuttings taken from container-grown stock plants exposed to eight concentrations of nitrogen $(\mathrm{N})$ (ranging from 0.4 to $14.1 \mathrm{~mm}$ ), seven concentrations of phosphorus (P) (ranging from 0.01 to $0.62 \mathrm{~mm}$ ), and five concentrations of potassium (K) (ranging from 0.25 to $5.33 \mathrm{~mm}$ ). Increases in $\mathrm{N}$ level negatively affected rooting rate and cutting survival. Propagation success was increased threefold as $\mathrm{N}$ in irrigation water was reduced from the highest to the lowest treatments. Enhanced root development under low $\mathbf{N}$ concentrations resulted in higher root weight compared with the high $\mathbf{N}$ concentrations. The high concentration of $\mathbf{N}$ fertilization negatively affected the propagation rate but was not reflected in $\mathrm{N}$ concentration of diagnostic leaves. There was, however, a significant negative correlation between $\mathbf{N}$ in twigs and propagation rate. Regarding response to $\mathrm{K}$ concentration, no effect was found on rooting rate or cutting survival. Except for reduced rooting at the lowest concentration, $P$ had a negligible effect on rooting rate. The experimental results indicate the need to avoid overfertilization of olive stock trees with $\mathbf{N}$ to promote successful propagation.

Olive oil production is historically important throughout the Mediterranean where there is evidence of human cultivation and consumption from as far back as 5000-6000 years ago (Vossen, 2007). Today the world has some 9.4 million ha of orchards producing 1.5 million tons of table olives and 16 million ton of olives that are processed into 2.56 million tons of oil (Vossen, 2007).

Olives are commonly propagated by leafy cuttings under mist (Peixe et al., 2007). Factors that may affect rooting rate of cuttings include: type of wood used, season, and cultivar. Rooting rate is highest from April to October (northern hemisphere) and cutting shoot growth is maximal during June to July. In winter, rooting rate and shoot growth are reduced (Fabbri et al., 2004). Cultivars differ widely in their ability to root. Some varieties produce roots from cuttings easily, whereas others are very difficult to root. The Greek 'Kalamata' (Sutter, 2005), the Tunisian 'Chemlali De Sfax' (Fabbri et al., 2004), the Spanish 'Gordal Sevillana' (Gonzalez Padilla et al., 2009), the Portuguese 'Galega vulgar' (Peixe et al., 2007), the Italian 'Leccio del Corno' (Bartolini et al., 2008), and the ornamental 'Swan Hill' (Sutter, 2005) are understood to be difficult-to-root cultivars. In such cultivars, grafting, despite its expense, can be

Received for publication 31 Oct. 2011. Accepted for publication 25 Dec. 2011.

${ }^{1}$ To whom reprint requests should be addressed; e-mail arnondag@agri.gov.il. the main method for propagation. One of the factors influencing rooting rate of cuttings of evergreen trees is stock-plant mineral nutrition (Blazich et al., 1988). Several studies evaluated the effect of fertilization regime (mainly regarding $\mathrm{N}$ ) of stock plants on propagation rate. Henry et al. (1992) studied the Eastern Redcedar, Raymer et al. (2008) studied the Seacoast Marshelder, and Rowe et al. (1999) evaluated the response of the Loblolly Pine. In general, but not always, higher $\mathrm{N}$ supplied to the stock plant resulted in lower propagation success. However, no such evaluation has been determined for olives. The global production of olive seedlings currently stands at $\approx 40$ million trees per year (Fabbri et al., 2004). This number is on the rise as a result of the expansion of olive cultivation and the increase in average tree density in orchards (De la Rosa et al., 2007). Increasing the rooting rate, especially in those cultivars that are difficult to root, would lower costs in the nursery and lower the price of seedlings. The objective of this study was, therefore, to investigate the manner in which $\mathrm{N}, \mathrm{P}$, and $\mathrm{K}$ fertilization of stock plants affects the propagation rates of rooted olives.

Olives from the cultivar Barnea (the main cultivar for oil production in intensive orchards in Israel) were grown in containers at the Gilat Research Center in Israel (lat. $31^{\circ} 20^{\prime} \mathrm{N}$, long. 3439' E). Two-year-old rooted cuttings, pruned to single 60 -cm-high

\section{Materials and Methods}

trunks, were planted in Feb. 2006 in 60-L (40.4 cm diameter and $47.0 \mathrm{~cm}$ depth) containers filled with Type $4(4-6 \mathrm{~mm})$ granular perlite substrate. Perlite was chosen to be the growth medium because of its preferable physical properties (high porosity and high hydraulic conductivity) and low interaction with nutrients. Initially, the trees were irrigated through a drip system with a solution containing $5.9 \mathrm{~mm} \mathrm{~N}\left(70 \% \mathrm{NO}_{3}{ }^{-}\right.$and $30 \%$ $\mathrm{NH}_{4}^{+}$), $0.51 \mathrm{~mm} \mathrm{P}, 1.8 \mathrm{~mm} \mathrm{~K}, 1.3 \mathrm{~mm}$ calcium (Ca), 0.9 mm magnesium $(\mathrm{Mg}), 0.6 \mathrm{~mm}$ sulfur (S), $0.023 \mathrm{~mm}$ boron (B), $10.7 \mu \mathrm{M}$ iron (Fe), $5.46 \mu \mathrm{M}$ manganese (Mn), $2.31 \mu \mathrm{M}$ zinc $(\mathrm{Zn})$, $0.35 \mu \mathrm{M}$ copper $(\mathrm{Cu})$, and $0.17 \mu \mathrm{M}$ molybdenum (Mo). In Sept. 2006, differential fertilization was initiated. Concentrations of individual minerals are presented in Table 1 for N, Table 2 for $\mathrm{P}$, and Table 3 for $\mathrm{K}$. The irrigation solutions were sampled and analyzed every 2 weeks, and the presented values are averages of all measurements. To analyze effects of $\mathrm{N}$ concentration on propagation variables, concentrations of $\mathrm{P}$ and $\mathrm{K}$ in the irrigation solution were maintained at $0.30 \pm 0.06($ mean $\pm \mathrm{SD})$ and $2.6 \pm 0.3 \mathrm{~mm}$, respectively. To analyze effects of $\mathrm{P}$ concentrations, $\mathrm{N}$ and $\mathrm{K}$ in the irrigation solution were maintained at $5.4 \pm$ 0.6 and $2.6 \pm 0.3 \mathrm{~mm}$, respectively. To analyze effects of $\mathrm{K}$ concentrations, $\mathrm{N}$ and $\mathrm{P}$ in the irrigation solution were maintained at $5.4 \pm$ 0.6 and $0.30 \pm 0.06 \mathrm{Mm}$, respectively. Nutrient solutions were prepared in $500-\mathrm{L}$ containers and included all additional nutrient elements. Concentrations of specific nutrients were: $1.3 \mathrm{~mm} \mathrm{Ca}, 0.67 \mathrm{~mm} \mathrm{Mg}, 1.1 \mathrm{~mm} \mathrm{~S}$, 0.023 mм B, $9.8 \mu \mathrm{M}$ Fe, $4.9 \mu \mathrm{M}$ Mn, $2.1 \mu \mathrm{M}$ $\mathrm{Zn}, 0.31 \mu \mathrm{M} \mathrm{Cu}$, and $0.16 \mu \mathrm{M}$ Mo. In all treatments, $\mathrm{N}$ was allocated as $90 \% \mathrm{NO}_{3}{ }^{-}$and $10 \% \mathrm{NH}_{4}{ }^{+}$. Solutions were prepared by dissolving $\mathrm{KH}_{2} \mathrm{PO}_{4}, \mathrm{~K}_{2} \mathrm{SO}_{4}, \mathrm{KNO}_{3}, \mathrm{NH}_{4} \mathrm{H}_{2} \mathrm{PO}_{4}$, $\mathrm{NaNO}_{3}$, and $\mathrm{NH}_{4} \mathrm{NO}_{3}$. Average electrical conductivity (EC) values for the solutions ranged from 0.9 to $2.1 \mathrm{dS} \cdot \mathrm{m}^{-1}$. Irrigation water $\mathrm{pH}$ was adjusted to a value of $6.0 \pm 0.2 \mathrm{using}$ $1.15 \mathrm{~N}$ sulphuric acid. Irrigation quantity was set to obtain $30 \%$ drainage by volume. Volume, $\mathrm{EC}$, and $\mathrm{pH}$ of the drainage water were measured twice a month. In Jan. 2008, the trees were transplanted into 500-L containers ( $82 \mathrm{~cm}$ diameter, $103 \mathrm{~cm}$ depth). The experiment used a randomized block design with three replications per treatment. To decrease spatial variability, rows of olive seedlings, planted in additional containers, were located around the perimeter of the experimental trees. Diagnostic leaves were sampled in July 2009 , the standard period for leaf analysis in Israel, and in Jan. 2010, close to cuttings collection. Fifty to 100 of the youngest fully developed leaves were collected from the middle portion of non-bearing branches. Sampled leaves were rinsed for $15 \mathrm{~s}$ in deionized water, dried at $60{ }^{\circ} \mathrm{C}$, and ground in a stainless steel coffee mill to particle size less than $0.5 \mathrm{~mm}$. Total $\mathrm{N}, \mathrm{P}$, and $\mathrm{K}$ concentrations of the leaves were determined after digestion with sulphuric acid and peroxide (Snell and Snell, 1949). The concentrations of $\mathrm{N}$ and $\mathrm{P}$ were determined with an autoanalyzer (Lachat Instruments, Milwaukee, WI) and K concentrations were analyzed with 
Table 1. Effect of stock plant nitrogen $(\mathrm{N})$ fertilization on rooting percentage, cutting survival, and consequential total propagation rate.

\begin{tabular}{|c|c|c|c|c|c|c|c|}
\hline \multirow[b]{2}{*}{ Treatment } & \multirow{2}{*}{$\begin{array}{l}\mathrm{N} \text { concn in } \\
\text { irrigation solution } \\
(\mathrm{mM} \pm \mathrm{SD})\end{array}$} & \multicolumn{2}{|c|}{$\begin{array}{l}\mathrm{N} \text { concn in diagnostic } \\
\text { leaves }(\% \mathrm{DM} \pm \mathrm{SD})\end{array}$} & \multirow{2}{*}{$\begin{array}{c}\text { Rooting } \\
(\%)\end{array}$} & \multirow{2}{*}{$\begin{array}{c}\text { Cutting } \\
\text { survival (\%) }\end{array}$} & \multirow{2}{*}{$\begin{array}{l}\text { Propagation } \\
\text { success }^{\mathrm{z}}(\%)\end{array}$} & \multirow{2}{*}{$\begin{array}{l}\text { Root dry } \\
\mathrm{wt}^{\mathrm{t}}(\mathrm{g})\end{array}$} \\
\hline & & July 2009 & Jan. 2010 & & & & \\
\hline N1 & $0.3 \pm 0.3$ & $0.72 \pm 0.04$ & $0.96 \pm 0.08$ & $38.2^{*}$ & 85.7 & $32.7^{*}$ & $0.60 \mathrm{a}$ \\
\hline N2 & & $1.38 \pm 0.24$ & $1.47 \pm 0.20$ & $33.3^{*}$ & 75.8 & $25.3^{*}$ & $0.42 \mathrm{ab}$ \\
\hline N3 & & $54 \pm 0.11$ & $1.68 \pm 0.09$ & 19.2 & 68 & 13. & $0.42 \mathrm{ab}$ \\
\hline N4 & $3.4 \pm 0.3$ & $1.66 \pm 0.14$ & $1.93 \pm 0.05$ & 18.2 & 50.0 & 9.1 & $0.49 \mathrm{ab}$ \\
\hline N5 & $5.5 \pm 0.6$ & $1.60 \pm 0.10$ & $1.90 \pm 0.15$ & 18.8 & 72.2 & 13.5 & $0.39 \mathrm{ab}$ \\
\hline N6 & $7.8 \pm 0.7$ & $1.55 \pm 0.07$ & $1.78 \pm 0.15$ & 12.4 & 50.0 & 6.2 & $0.25 \mathrm{~b}$ \\
\hline N7 & $10.9 \pm 1.1$ & $1.64 \pm 0.07$ & $1.92 \pm 0.21$ & $8.1^{*}$ & 25.0 & $2.0^{*}$ & $0.38 \mathrm{ab}$ \\
\hline $\mathrm{N} 8$ & 14. $4 \pm 1.2$ & $1.91 \pm 0.15$ & $2.06 \pm 0.14$ & 17.9 & 47.1 & 8.4 & $0.25 \mathrm{~b}$ \\
\hline
\end{tabular}

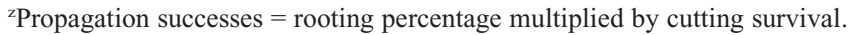

${ }^{y}$ Any two means within a column for a single parameter not followed by the same letter are significantly different at $P<0.05$.

*Significant at $P=0.01$ by Chi-squared test.

$\mathrm{DM}=$ dry matter.

Table 2. Effect of stock plant phosphorus (P) fertilization on rooting percentage, cutting survival, and consequential total propagation rates.

\begin{tabular}{|c|c|c|c|c|c|c|c|}
\hline \multirow[b]{2}{*}{ Treatment } & \multirow{2}{*}{$\begin{array}{c}\text { P concn in } \\
\text { irrigation solution } \\
(\mathrm{mM} \pm \mathrm{SD})\end{array}$} & \multicolumn{2}{|c|}{$\begin{array}{l}\mathrm{P} \text { conen in diagnostic } \\
\text { leaves }(\% \mathrm{DM} \pm \mathrm{SD})\end{array}$} & \multirow{2}{*}{$\begin{array}{l}\text { Rooting } \\
(\%)\end{array}$} & \multirow{2}{*}{$\begin{array}{l}\text { Cutting } \\
\text { survival } \\
(\%)\end{array}$} & \multirow{2}{*}{$\begin{array}{l}\text { Propagation } \\
\text { rates } \\
(\%)^{z}\end{array}$} & \multirow{2}{*}{$\begin{array}{c}\text { Root } \\
\text { dry } \\
\mathrm{wt}^{\mathrm{y}}(\mathrm{g})\end{array}$} \\
\hline & & July 2009 & Jan. 2010 & & & & \\
\hline P1 & $0.01 \pm 0.01$ & $0.03 \pm 0.00$ & $0.04 \pm 0.00$ & $3.5^{*}$ & 50.0 & 1.7 & $0.29 \mathrm{a}$ \\
\hline P2 & $0.02 \pm 0.01$ & $0.08 \pm 0.01$ & $0.08 \pm 0.02$ & 23.5 & 78.3 & 18.4 & $0.32 \mathrm{a}$ \\
\hline P3 & $0.04 \pm 0.01$ & $0.09 \pm 0.01$ & $0.09 \pm 0.02$ & 19.6 & 52.6 & 10.3 & $0.36 \mathrm{a}$ \\
\hline P4 & $0.07 \pm 0.01$ & $0.17 \pm 0.02$ & $0.14 \pm 0.03$ & 25.0 & 62.5 & 15.6 & $0.50 \mathrm{a}$ \\
\hline P5 & $0.16 \pm 0.03$ & $0.16 \pm 0.01$ & $0.15 \pm 0.00$ & 10.6 & 71.4 & 7.6 & $0.20 \mathrm{a}$ \\
\hline P6 & $0.32 \pm 0.03$ & $0.20 \pm 0.02$ & $0.19 \pm 0.01$ & 18.8 & 72.2 & 13.5 & $0.39 \mathrm{a}$ \\
\hline P7 & $0.64 \pm 0.04$ & $0.25 \pm 0.02$ & $0.23 \pm 0.04$ & 26.3 & 61.5 & 16.2 & $0.32 \mathrm{a}$ \\
\hline
\end{tabular}

${ }^{2}$ Propagation rates $=$ rooting percentage multiplied by cutting survival.

${ }^{y}$ Any two means within a column for a single parameter not followed by the same letter are significantly different at $P<0.05$.

* Significant at $P=0.01$ by Chi-squared test.

$\mathrm{DM}=$ dry matter.

Table 3. Effect of stock plant potassium (K) fertilization on rooting percentage, cutting survival, and the consequential total prorogation rates.

\begin{tabular}{|c|c|c|c|c|c|c|c|}
\hline \multirow[b]{2}{*}{ Treatment } & \multirow{2}{*}{$\begin{array}{l}\text { K concn in } \\
\text { irrigation solution } \\
(\mathrm{mM} \pm \mathrm{SD})\end{array}$} & \multicolumn{2}{|c|}{$\begin{array}{l}\mathrm{K} \text { concn in diagnostic } \\
\text { leaves }(\% \mathrm{DM} \pm \mathrm{SD})\end{array}$} & \multirow{2}{*}{$\begin{array}{c}\text { Rooting } \\
\text { (\%) }\end{array}$} & \multirow{2}{*}{$\begin{array}{l}\text { Cutting } \\
\text { survival } \\
(\%)\end{array}$} & \multirow{2}{*}{$\begin{array}{c}\text { Propagation } \\
\text { rate }^{\mathrm{z}} \\
(\%)\end{array}$} & \multirow{2}{*}{$\begin{array}{c}\text { Roots } \\
\text { dry } \\
\text { wt }^{y}(g)\end{array}$} \\
\hline & & July 2009 & Jan. 2010 & & & & \\
\hline$\overline{\mathrm{K} 1}$ & $0.24 \pm 0.01$ & $0.33 \pm 0.04$ & $0.37 \pm 0.10$ & 20.7 & 55.0 & 11.5 & $0.35 \mathrm{a}$ \\
\hline $\mathrm{K} 2$ & $0.49 \pm 0.09$ & $0.99 \pm 0.03$ & $0.80 \pm 0.04$ & 19.8 & 63.2 & 12.4 & $0.18 \mathrm{a}$ \\
\hline K3 & $0.75 \pm 0.12$ & $1.25 \pm 0.18$ & $1.00 \pm 0.01$ & 19.1 & 42.1 & 8.1 & $0.38 \mathrm{a}$ \\
\hline K4 & $2.07 \pm 0.23$ & $1.51 \pm 0.04$ & $1.44 \pm 0.16$ & 9.3 & 66.7 & 6.1 & $0.22 \mathrm{a}$ \\
\hline K5 & $2.68 \pm 0.28$ & $1.57 \pm 0.06$ & $1.44 \pm 0.14$ & 18.9 & 72.2 & 13.5 & $0.39 \mathrm{a}$ \\
\hline K6 & $5.23 \pm 0.38$ & $2.01 \pm 0.13$ & $1.88 \pm 0.08$ & 16.6 & 63.6 & 10.6 & $0.26 \mathrm{a}$ \\
\hline
\end{tabular}

${ }^{\text {zPropagation successes }}=$ rooting percentage multiplied by cutting survival.

${ }^{y}$ Any two means within a column for a single parameter not followed by the same letter are significantly different at $P<0.05$.

$\mathrm{DM}=$ dry matter.

a flame photometer (Model 400; Corning, Corning, NY). Twigs (young shoots, less than $5 \mathrm{~mm}$ diameter) were sampled from the $\mathrm{N}$ treatment stock plants in Dec. 2009. Twigs, without leaves, were analyzed for $\mathrm{N}$ content as described previously for leaves.

In Jan. 2010, shoots were cut from the experimental trees. Thirty-three cuttings were taken from each tree. Each cutting was $\approx 10 \mathrm{~cm}$ long. Leaves were removed from the base of cuttings leaving six leaves at the apex. After diagonal slices were made at the base of each cutting, they were soaked in water and coated with Hormoril T-8 (Merhav-Agro; O.8\% indole-3-butyric acid $+5 \%$ tiabendazole). Each coated cutting was inserted into a propagation plug ('Speedplugs' produced by Tuff Substrates, Merom Golan, Israel; 30\% Fine Baltic Peat, $60 \%$ polystyrene foam, and $10 \%$ vermiculite) and placed in a rooting bed under mist. Mist was applied between 0700 and $1600 \mathrm{HR}$ for $10 \mathrm{~s}$ every $15 \mathrm{~min}$. The cuttings were routinely examined and, when roots appeared outside the plug, they were transplanted into 0.5 -L plastic pots filled with commercial potting mix (peat and vermiculite at a ratio of $1: 1$ by volume, $\mathrm{pH}$ 7.6) and placed in a greenhouse. Rooting percentage was determined in late June by dividing the number of rooted cuttings per tree by 33 (the initial number of cuttings per stock tree). The rooted cuttings were left to grow in the greenhouse until 15 Nov. Thereafter, the rate of survival was determined by dividing the sum of developed transplants per tree by the number of initial rooted cuttings. Biomass of developed roots was determined. Roots were separated, oven-dried at $60{ }^{\circ} \mathrm{C}$, and weighed.

Data were analyzed using JMP 5.0 software (SAS Institute Inc., Cary, NC). Effects of the various treatments on rooting percentage, cutting survival, and propagation success were analyzed categorically (binary) by chi-squared test examining the hypothesis of homogenous population between treatments $(P \leq 0.01)$. Root dry weight was examined by analysis of variance and, whenever treatment effect was significant, differences between treatments were determined using the Tukey-Kramer honestly significant difference test (at $P \leq 0.05$ ). The relationships between propagation success and $\mathrm{N}$ concentration in irrigation solution, twigs, and diagnostic leaves were determined using curve-fitting and analysis tools of SigmaPlot 9.01 (Systat Software, Inc., Point Richmond, CA). Exponential decay regression was fitted for all figures.

\section{Results}

Nitrogen concentration in leaves sampled on July 2009 ranged from $0.72 \%$ to $1.91 \%$. In Jan. 2010, close to the time of cutting collection, leaf $\mathrm{N}$ increased for all $\mathrm{N}$ treatments and ranged from $0.96 \%$ to $2.06 \%$ (Table 1 ). For both dates, the leaf concentration-irrigation solution concentration relationships were not linear. Smaller changes in leaf $\mathrm{N}$ were observed when the element was found at high concentrations in the irrigation solution, resulting in saturation curves. Rooting percentage was significantly affected by $\mathrm{N}$ treatments. Rooting percentage was significantly higher for the two lowest $\mathrm{N}$ treatments, whereas that of treatment N7 was found to be significantly lower. Although insignificant, cutting survival was higher for the lower $\mathrm{N}$ treatments and gradually declined with increasing $\mathrm{N}$ exposure rate. Propagation rate was the result of combined rooting success and cutting survival and was quantified as the percentage of viable rooted cuttings in the total number of cuttings that were taken. The two lowest $\mathrm{N}$ treatments resulted in more than three times greater root cuttings success $(25 \%$ and $33 \%)$ compared with the three highest $\mathrm{N}$ treatments (2\% to $8 \%$; Table 1). The stock trees receiving low levels of $\mathrm{N}$ also had greater root dry weights. Treatment $\mathrm{N} 1$ had $0.6 \mathrm{~g}$ dry roots per plant, whereas treatment $\mathrm{N} 8$ had only $0.25 \mathrm{~g}$ roots (Table 1 ). Propagation success rate was strongly a function of irrigation solution $\mathrm{N}$ concentration. Percent success was reduced in an exponential decay fashion with increased $\mathrm{N}$ in water (Fig. 1A). Leaf matter N (Fig. 1C-D) was correlated less well to propagation rate as compared with twig $\mathrm{N}$ concentration (Fig. 1B). Twig $\mathrm{N}$ was also best represented by the exponential decay function, this despite the fact that twig $\mathrm{N}$ concentrations were the same for the three highest treatment levels. 

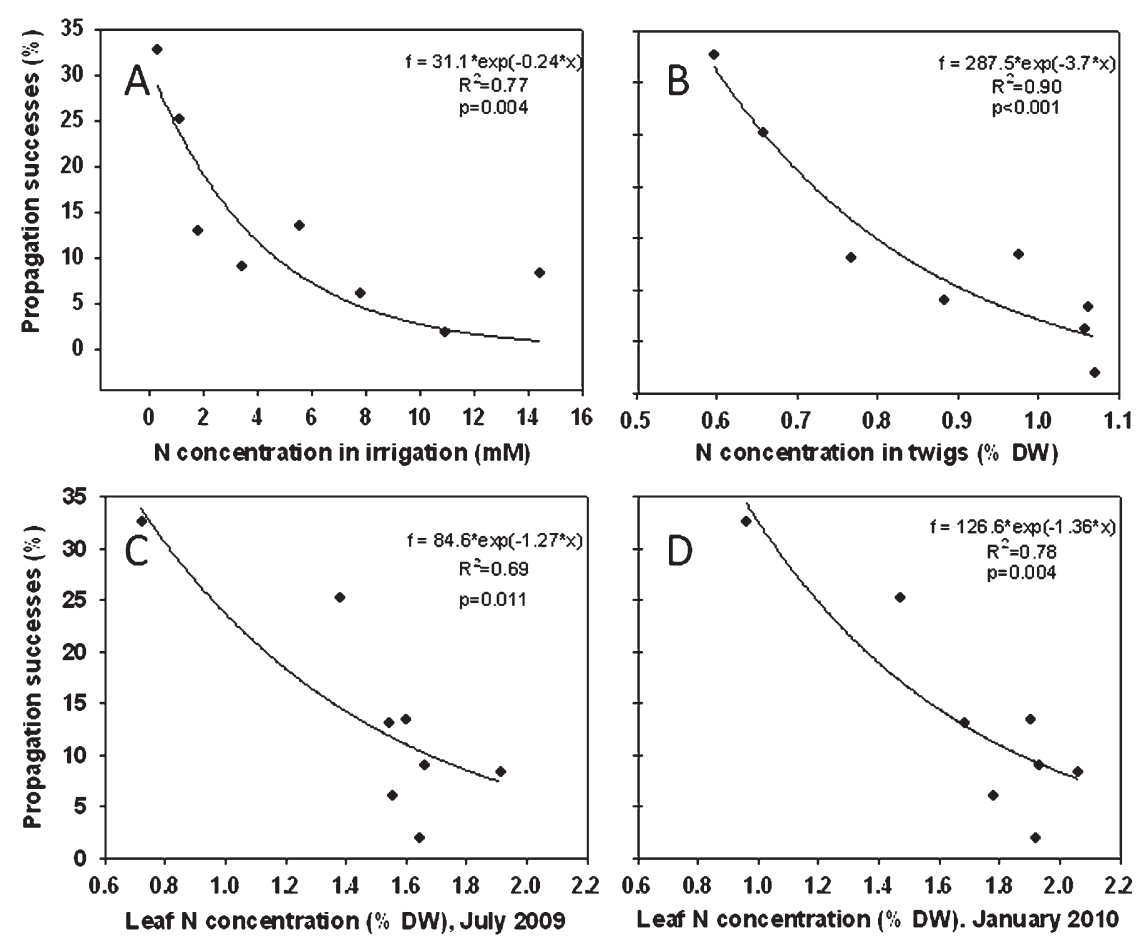

Fig. 1. Effect of nitrogen (N) concentration in irrigation solution (A), in twigs without the leaves (Dec. 2009) (B), in diagnostic leaves from July 2009 (C), and in diagnostic leaves from Jan. 2010 (D) on the propagation success. Markers represent the average obtained from three stock plants receiving the same level of $\mathrm{N}$ fertilization. All figures were fitted with exponential decay regression.

Increased levels of $\mathrm{P}$ fertilization resulted in continuous $\mathrm{P}$ increase in diagnostic leaves with values ranging from $0.03 \%$ to $0.25 \%$ and $0.04 \%$ to $0.23 \%$ (July and January, respectively) between $\mathrm{P} 1$ to $\mathrm{P} 7$ treatments, respectively (Table 2 ). The only significant effect of $\mathrm{P}$ fertilization level on rooting percentage was found when comparing the lowest $\mathrm{P}(\mathrm{P} 1)$ treatment (average 3.5\%) to the higher $\mathrm{P}$ levels (P2 to P7), which averaged 20.6\% (Table 2). No significant effect of $P$ fertilization level was found on cutting survival or on root dry weight. Total propagation success was lower in the P1 treatment as a result of its low rooting percentage (Table 2).

Increased levels of $\mathrm{K}$ fertilization resulted in continuous increase of $\mathrm{K}$ in leaves and ranged between $0.33 \%$ to $2.01 \%$ and $0.37 \%$ to $1.88 \%$ for K1 to K7 treatments for July and January, respectively (Table 3). No significant effect of $\mathrm{K}$ fertilization level was found on cutting survival or on root dry weight (Table 3).

\section{Discussion}

Micropropagation (producing progeny plants using plant tissue culture methods) has proven to be a possible alternative in many cases where traditional methods for the propagation of fruit species are unsuccessful. However, there is not yet enough knowledge to depend on the use of micropropogation in mass scale nursery production of olives (Zuccherelli and Zuccherelli, 2002). Many olive cultivars are considered difficult to root. Despite the crop's importance, no previous studies have been performed on the effect of olive stock plant nutritional status on propagation rates. In vitro rooting ability depends on many endogenous and exogenous factors such as genetic background, physiological influences, environment (light and temperature), composition of the nutrient medium, age, and the ontogenetic phase of the mother plant (Németh, 1986). In the current study, we explored the effect of nutritional status of the stock plant on rooting rates of olive (cv. Barnea). Mineral concentration in diagnostic leaves serves as a benchmark for nutritional status of olive trees (López-Villalta, 1996). Adequate concentration of $\mathrm{N}$ in diagnostic leaves is considered to be between $1.5 \%$ and 2.0\% (Fernández-Escobar, 2004). Analysis of diagnostic leaves in the current experiment indicated that trees in the $\mathrm{N} 1$ treatment $(0.3 \mathrm{~mm} \mathrm{~N}$ in irrigation solution) suffered from severe $\mathrm{N}$ deficiency, whereas trees receiving the $\mathrm{N} 2$ treatment $(1.1 \mathrm{~mm} \mathrm{~N})$ experienced slight $\mathrm{N}$ deficiency (Table 1; Fig. 1B). Although deficiencies can be detected easily in leaf analysis, this in not true for excess levels of $\mathrm{N}$ because increased exposure to $\mathrm{N}$ has been found to effect plant behavior, although not indicated by $\mathrm{N}$ concentration in diagnostic leaves (FernándezEscobar et al., 2011). In the current work, there was a strong negative response of propagation rates as a function of the $\mathrm{N}$ concentration in tissue from twigs (Fig. 1B). Leaf analysis indicated that trees of treatments P1 to P3 (0.04 mm and less) were P-deficient, whereas trees of treatments $\mathrm{P} 4$ to $\mathrm{P} 7$ treatments (0.07 mM P and greater) had sufficient $\mathrm{P}$ (Table 2). As for K, only trees of the K1 treatment had leaf $\mathrm{K}$ concentrations indicative of deficiency (Table 3) (Fernández-Escobar et al., 2004).

The generally low propagation rates in the current experiment (only up to $30 \%$ of the cuttings resulted in vigorous developing plants) may be explained by rooting seasonality in olive as reported by Hartmann and Loreti (1965) and Mencuccini (2003) who showed relatively low rooting percentage in winter. Further study is required to evaluate the effect of $\mathrm{N}$ fertilization on stock plants during more favorable rooting seasons (summer) as well as on varieties that are more difficult to root than Barnea.

From our results it seems that high levels of $\mathrm{N}$, which may be optimal for plant growth and cutting production, negatively affect propagation success and root biomass production. This inverse relationship has been previously demonstrated for cuttings taken from stock plants of geranium, azalea, and eastern red cedar (Haun and Cornell, 1951; Henry et al., 1992; Preston et al., 1953). The cause for reduced propagation rates when high $\mathrm{N}$ levels are applied can be the result of the reduction in starch reserves in the cuttings (Rowe et al., 1999). Stem cuttings must have an adequate supply of carbohydrates during root initiation (Bhattacharya et al., 1976; Ochoa et al., 2004). However, in contrast to our findings, Rowe et al. (1999) working on loblolly pine (Pinus taeda L.), reported decreased rooting with lower levels of $\mathrm{N}$ in stock plants. Regarding cutting survival, this study showed results similar to ours, in which rooted cutting survival declined with increased $\mathrm{N}$ in stock plants.

In conclusion, $\mathrm{N}$ concentrations were generally higher in cuttings taken from stock plants exposed to higher $\mathrm{N}$ in the irrigation solution. Cuttings removed from stock plants receiving low $\mathrm{N}$ fertilization rooted better and had a higher survival rate, resulting in a better overall propagation rate when $\mathrm{N}$ fertilization was reduced. Of course, reducing $\mathrm{N}$ drastically would be expected to limit stock plant growth and decrease the amount of available material for cuttings. Therefore, the propagator should first supply sufficient $\mathrm{N}$ for shoot growth and subsequently reduce $\mathrm{N}$ fertilization before cutting removal. As for $\mathrm{K}$ and $\mathrm{P}$, they seem to play minor roles in the propagation process and, therefore, their fertilization level can be as for commercially grown mature olive trees.

\section{Literature Cited}

Bartolini, G., R. Petruccelli, P. Pestelli, R. Bernardi, and M. Durante. 2008. Preliminary study on in vivo rooting of two Olea europaea L. genotypes. Acta Hort. 791:191-196.

Bhattacharya, N.C., S.S. Parmer, and K.K. Nanda. 1976. Isoenzyme polymorphism of amylase and catalase in relation to rooting etiolated stem segments of Populus nigra. Biochem. Physiol. Pflanz. 170:133-142.

Blazich, F.A. 1988. Mineral nutrition and adventitious rooting, p. 61-69. In: Davis, T.D., B.E. Haissig, and N. Sankhla (eds.). Adventitious root formation in cuttings. Dioscorides Press, Portland, OR

De la Rosa, R., L. León, N. Guerrero, L. Rallo, and D. Barranco. 2007. Preliminary results of an 
olive cultivar trial at high density. Aust. J. Agr. Res. 58:392-395.

Fabbri, A., G. Bartolini, M. Lombardi, and S. Kailis. 2004. Olive propagation manual. CSIRO Publishing, Melbourne, Australia.

Fernández-Escobar, R. 2004. Fertilización, El cultivo del olivo. p. 237-257. Ediciones MundiPresna, Madrid, Spain.

Fernández-Escobar, R., J.M. Garcia-Novelo, and H. Resttrepo-Diaz. 2011. Mobilization of nitrogen in the olive bearing shoots after foliar application of urea. Sci. Hort. 127:452-454.

Gonzalez Padilla, I.M., I. Vidoy, and C.L. Encina. 2009. Influence of indole-butyric acid and electro-pulse on in vitro rooting and development of olive (Olea europea L.) microshoots. Plant Cell Rpt. 28:1411-1420.

Hartmann, H.T. and F. Loreti. 1965. Seasonal variation in the rooting of olive cuttings. Proc. Am. Soc. Hort. Sci. 87:194-198.

Haun, J.R. and P.W. Cornell. 1951. Rooting response of geranium (Pelargonium bortorum, Baily var. Richard) cuttings as influenced by nitrogen, phosphorous and potassium nutrition on the stock plant. Proc. Amer. Soc. Hort. Sci. 58:317-323.

Henry, P.H., F.A. Blazich, and L.E. Hinesley. 1992. Nitrogen nutrition of containerized eastern redcedar. 2. Influence of stock plant fertility on adventitious rooting of stem cuttings. J. Amer. Soc. Hort. Sci. 117:568-570.

López-Villalta, L.C. 1996. The importance of nutrients in olive orchards, p. 159-161. In: International Olive Oil Council (ed.). World Olive Encyclopedia. International Olive Oil Council, Madrid, Spain.

Mencuccini, M. 2003. Effect of medium darkening on in vitro rooting capability and rooting seasonality of olive (Olea europaea L.) cultivars. Sci. Hort. 97:129-139.

Németh, G. 1986. Induction of rooting, p. 49-64. In: Bajaj, Y.P.S. (ed.). Biotechnology in agriculture and forestry. I. Trees. Springer, Berlin, Germany.

Ochoa, J., S. Banon, J.A. Fernandez, J.A. Franco, and J. Martinez-Sanchez. 2004. Rooting medium temperature and carbohydrates affected oleander rooting. Acta Hort. 659:239-244.

Peixe, A., A. Raposo, R. Lourenco, H. Cardoso, and E. Macedo. 2007. Coconut water and BAP successfully replaced zeatin in olive (Olea europaea L.) micropropagation. Scienia Hort. 113:1-7.

Preston, W.H., Jr., J.B. Shanks, and P.W. Cornell. 1953. Influence of mineral nutrition on production, rooting and survival of cutting of azalea. Proc. Amer. Soc. Hort. Sci. 61:499-507.

Raymer, J., M. Thetford, and D.L. Miller. 2008. Fertility rate of seacoast marshelder stock plants influence cutting production and rooting characteristics of steam cuttings. HortTechnology 18:372-378.

Rowe, D.B., F.A. Blazich, and R.J. Weir. 1999. Mineral nutrient and carbohydrate status of loblolly pine during mist propagation as influenced by stock plant nitrogen fertility. HortScience 34:1279-1285.

Snell, F.D. and C.T. Snell. 1949. Colorimetric methods analysis including some turbidimetic and nephelometric methods. Vol. 2. Inorganic. Van Nostrand, Toronto, Canada.

Sutter, E.G. 2005. Olive cultivars and propagation, p. 19-26. In: Sibbet, G.S. and L. Ferguson (eds.). Olive production manual. University of California, Agriculture and Natural Resources, Oakland, CA

Vossen, P. 2007. Olive oil: History, production and characteristics of the world's classic oils. HortScience 42:1093-1110.

Zuccherelli, G. and S. Zuccherelli. 2002. In vitro propagation of 50 olive cultivars. Acta Hort. 586:931-934. 